\section{Antibiotics self-medication among medical students in a new medical college at Abubakar Tafawa Balewa University Bauchi, Nigeria}

\author{
Yusuf Abdu Misau, ${ }^{1,2}$ \\ Alkali Mohammed, ${ }^{3}$ Yusuf Bara Jibrin, ${ }^{3}$ \\ Sabiu Abdu Gwalabe, ${ }^{3}$ \\ Sunusi Usman Usman, ${ }^{4}$ \\ Bashir Muhammad Faruk, 5 \\ Dominic Mogere, ${ }^{2}$ S.A. Mbaruk ${ }^{2}$ \\ ${ }^{1}$ Department of Community Medicine, \\ Abubakar Tafawa Balewa University \\ Bauchi, Nigeria; ${ }^{2}$ Department of \\ Epidemiology and Biostatistics, School \\ of Public Health, Mount Kenya \\ University, Thika, Kenya; ${ }^{3}$ Department \\ of Medicine, Abubakar Tafawa Balewa \\ University Teaching Hospital Bauchi, \\ Nigeria; ${ }^{4}$ Department of Public Health, \\ Faculty of Medical Sciences, Bauchi \\ State University, Gadau, Nigeria; \\ ${ }^{5}$ Department of Pediatrics, Abubakar \\ Tafawa Balewa University Teaching \\ Hospital Bauchi, Nigeria; ${ }^{6}$ Department \\ of Obstetrics and Gynecology, Abubakar \\ Tafawa Balewa University Teaching \\ Hospital, Bauchi, Nigeria
}

\begin{abstract}
Life as a medical student is often full of stress which could be physical, social, emotional and economical, especially in developing countries. Of recent, there has been an increased effort to combat self-medication which has remained a global public health burden since antiquity. Trainee health workers are particularly vulnerable to engage in self-medication practice which has remain a great panacea mitigating the efforts to combat resistance to common antibiotics in communities. This study aims to assess antibiotics self-medication among undergraduate medical students in Abubakar Tafawa Balewa University, Bauchi Nigeria. An exploratory cross-sectional study was conducted at college of medical sciences Abubakar Tafawa Balewa University Bauchi between June and July 2018. First and second year registered undergraduate medical students were specifically enrolled in the study. A sample size of 61 participants was determined by using a single population proportion formula and a close ended 25 items self-administered study tool was developed and piloted following a review of the relevant literature. All responses were analyzed
\end{abstract}

using SPSS Version 21 and STATA Version 13 software for statistical analysis. A total of Eighty-one (81) medical Students were enrolled in the study. There were 39 (48.1\%) males and $42(51.9 \%)$ females. The median age among all respondents was 20 years. $41 \%$ of all the students reported having selfmedication. (22) $27.2 \%$ of the respondent's reasons for self-medication was "Doctors gives same drug", for (20) $24.7 \%$ "the disease was mild", while (16) $19.7 \%$ "knew the drug to take", while (9) $11.1 \%$ "saves time" in self-medication and (2) $2.5 \%$ said it "saved cost". On logistic regression, gender remains the statistically significant explanatory variable, Wald Chi-square test 6.050 odds ratio 2.019 (P-value: 0.0014). The prevalence of SM among medical students is high in among Medical Students in ATBU Bauchi Nigeria. Targeted campaign programs to decrease SM among medical students in North East Nigeria as a whole, are required. Enforcement of laws and policies on un-prescribed drugs and continuous monitoring of dispensaries/drugstores and other outlets to issue drugs only on prescription are necessary to reduce self-medication.

\section{Introduction}

It has been a common culture among physicians and medical students to treat their medical ailments instead of subjecting themselves to formal care by another professional colleague even when physicians expects patients to subject themselves for medical care. ${ }^{1}$ The practice of Self-medication (SM) by health care providers is a potential source of occupational hazard. ${ }^{2}$ This has prompted interest in studying the relationship between health literacy and SM practice, ${ }^{3}$ which ironically has been defined as the act of taking drugs without the prescription of a legally qualified medical or health care provider. ${ }^{4}$ Antibiotics self-medication (ASM) specifically is being widely practiced globally with varying negative consequences. Although SM has been described elsewhere in the literature as a component of "self-care" and thus with potential benefits if used responsibly, ${ }^{5}$ whereas, self-care only involves use of over the counter medications which are lawfully used without being prescribed to treat selfperceived symptoms. ${ }^{6}$ ASM on the other side, involves mainly the use of prescription only antibiotics medicine, inappropriately by individuals and usually causing huge public health challenges. ${ }^{7}$

ASM among both medical care providers and future medical care providers (Students) has been a great source of global public health dilemma in recent years.
Correspondence: Yusuf A. Misau, Department of Community Medicine, Abubakar Tafawa Balewa University Bauchi, Nigeria.

E-mail: yusufmisau@gmail.com

Key words: Antibiotics; Medical Students; Self-Medication.

Contributions: The authors contributed equally.

Conflict of interest: The authors declare no potential conflict of interest.

Funding: None.

Received for publication: 13 September 2018. Revision received:22 August 2019.

Accepted for publication: 3 September 2019

This work is licensed under a Creative Commons Attribution NonCommercial 4.0 License (CC BY-NC 4.0).

${ }^{\circ}$ Copyright: the Author(s), 2019

Licensee PAGEPress, Italy

Pyramid Journal of Medicine 2019; 2:25

doi:10.4081/pjm.2019.25

Studies have reported the prevalence of ASM among undergraduate medical students in particular ranging from $20-100 \%$ underscoring the magnitude of the public health challenges it poses. ${ }^{8}$ Nigeria, is listed among resource limited countries which are shown to have higher proportion of inappropriate antibiotics users compared with industrialized nations. ${ }^{9}$ In addition, currently there is no nationally adapted definition of SM as well as ASM. Furthermore, gaps in legislations regulating the availabilities of prescription medicine accentuate access to these drugs through patent medicine stores. In a recent community-based study in Lagos, SM was found to be $93 \%$ among the respondents, ${ }^{10}$ while $96.2 \%$ of physicians in Nigeria were also shown to practice SM. ${ }^{11}$ Despite the relatively high reported prevalence of SM from community-based studies and among health care providers in Nigeria, to the best of our literature review there has been no studies on prevalence of antibiotics SM among medical students in Nigeria. This study therefore is aimed at providing the prevalence and knowledge of effects of antibiotics SM among medical students in college of medical sciences ATBU Bauchi Nigeria.

\section{Materials and Methods}

An exploratory cross-sectional study was conducted at College of medical sciences Abubakar Tafawa Balewa University Bauchi between June and July 2018. The 
study was targeted at all medical students in the college of medical sciences of the University.

First and second year registered undergraduate medical students in the study area were specifically enrolled in the study. The sample size was determined by using a single population proportion formula and considering the following assumptions: Prevalence (p) KAP of self-medication $50 \%,(\mathrm{Z})=$ standard normal distribution value at $95 \%$ confidence level of $Z \alpha / 2=$ 1.96 and margin of error $(d)=5 \%$.

$$
\begin{gathered}
\mathrm{N}=\frac{(\mathrm{Z} \alpha / 2)^{2} \times \mathrm{P}(1-\mathrm{P})}{\mathrm{d}^{2}} \\
\mathrm{n}=\frac{(1.96)^{2} \times 0.5(1-0.5)}{(0.05)^{2}} \\
\mathrm{n}=215
\end{gathered}
$$

The final sample size was determined as follows using correction formula.

$$
\mathrm{nf}=\mathrm{no} /[1+\mathrm{no} / \mathrm{N}]
$$

where $\mathrm{nf}=$ the final sample size; no = initial sample size which is 215 and $\mathrm{N}=$ number of medical students in Abubakar Tafawa Balewa university Bauchi State, Nigeria.

$$
\mathrm{nf}=(215 / 215) /[1+86]=61 \text { students }
$$

A close ended 25 items self-administered study tool was developed following a review of the relevant literature. The study tool was divided into three sections: i) Respondents' biodata; ii) Antibiotics SelfMedication Behavior; iii) Knowledge about antibiotics use and its effects.

\section{Study tool validation}

\section{Unidimensionality}

Structural Equation Modeling was conducted post hoc using STATA 13. A pooled measurement method was used. Items deletions method was used, starting with items that had lowest loading. Model estimations were repeated until all factors were loaded with values above 0.5 (as recommended for modified/new tool) to attain unidimensionality. ${ }^{12}$

\section{Validity}

Content and face validity

Five selected respondents were asked to comment about difficulties in answering the questionnaire, length of the items, tautology, ambiguity and depth of the thoughts in construction of the questionnaire items.
Responses from the pilot study were used to effect necessary corrections in the wordings of the questionnaire. ${ }^{13}$

Discriminant validity

This was achieved in the final model when all correlations between variables were less than 0.85 . Hence there is no collinearity. ${ }^{14}$

\section{Reliability test}

Internal reliability

Cronbach's alpha was calculated to measure the internal consistency ("reliability") of the study tool using SPSS software. A Cronbach's alpha of 0.741 signifies strong correlation between variables. There should be no significant change in "Cronbach's Alpha if Items are deleted" consistently in items assessed. ${ }^{15}$

Constructs reliability

To achieve this, a CR value was calculated. A CR value greater than 0.6 is required to ensure construct reliability is achieved. ${ }^{16}$

\section{Data collection}

Data collections were done by issuance of self-administered respondent's questionnaire by trained research assistant. Responses were obtained on the spot from consenting participants.

\section{Data analysis}

All responses were entered into spread sheet for data cleaning and subsequently transferred into SPSS version 21 and STATA version 13 software for statistical analysis. Respondents' demographic profile were summarized using frequency table followed by prevalence rates and proportion. Logistic regression was used to explore relation between SM practice as dependent variable with other construct domains as independent variables.

Ethical approval was obtained from the College of Medical Sciences, ATBU and informed consent from the respondents. All respondents were assured free will to participate or not in the study. They were further assured that all information provided will remain anonymous. Where respondents chose not to participate, they were assured no harm will result from their decision.

\section{Results}

\section{Socio demographics of respondents}

A total of Eight-one (81) medical Students were enrolled in the study. There were $39(48.1 \%)$ males and $42(51.9 \%)$ females. The median age among all respon-

\begin{tabular}{|c|c|c|}
\hline Variables & Frequency & $\begin{array}{c}\text { Percentage } \\
\text { (\%) }\end{array}$ \\
\hline $\begin{array}{l}\text { Gender } \\
\text { Male } \\
\text { Female }\end{array}$ & $\begin{array}{l}39 \\
42\end{array}$ & $\begin{array}{l}48.1 \\
51.9\end{array}$ \\
\hline $\begin{array}{l}\text { Age } \\
\qquad 15-20 \\
21-25 \\
26-30 \\
\text { 31-above }\end{array}$ & $\begin{array}{c}63 \\
16 \\
1 \\
1\end{array}$ & $\begin{array}{c}77.8 \\
19.8 \\
1.2 \\
1.2\end{array}$ \\
\hline $\begin{array}{c}\text { Level of Study } \\
100 \text { Level } \\
200 \text { Level }\end{array}$ & $\begin{array}{l}55 \\
26\end{array}$ & $\begin{array}{l}67.9 \\
32.1\end{array}$ \\
\hline $\begin{array}{l}\text { Marital Status } \\
\text { Married } \\
\text { Single } \\
\text { Divorced }\end{array}$ & $\begin{array}{c}3 \\
78 \\
0\end{array}$ & $\begin{array}{c}3.7 \\
96.7 \\
0\end{array}$ \\
\hline $\begin{array}{l}\text { Tribe } \\
\text { Hausa } \\
\text { Yoruba } \\
\text { Igbo } \\
\text { Others }\end{array}$ & $\begin{array}{l}78 \\
2 \\
1 \\
0\end{array}$ & $\begin{array}{c}96.3 \\
2.5 \\
1.2 \\
0\end{array}$ \\
\hline $\begin{array}{l}\text { State of origin } \\
\text { Adamawa } \\
\text { Bauchi } \\
\text { Borno } \\
\text { Gombe } \\
\text { Kaduna } \\
\text { Kano } \\
\text { Kastina } \\
\text { Kwara } \\
\text { Nasarawa } \\
\text { Osun } \\
\text { Taraba } \\
\text { Yobe }\end{array}$ & $\begin{array}{l}1 \\
57 \\
2 \\
2 \\
1 \\
2 \\
3 \\
1 \\
2 \\
1 \\
5 \\
2\end{array}$ & $\begin{array}{c}12 \\
70.4 \\
2.5 \\
2.5 \\
1.2 \\
2.5 \\
3.7 \\
1.2 \\
2.5 \\
1.2 \\
6.2 \\
2.5\end{array}$ \\
\hline $\begin{array}{l}\text { Mothersage } \\
\text { Do not know the age } \\
\text { Deceased } \\
\text { 30-40 Years } \\
\text { 41-50 Years } \\
\text { 51-60 Years } \\
\text { 61-70 Years }\end{array}$ & $\begin{array}{c}13 \\
5 \\
20 \\
33 \\
9 \\
1\end{array}$ & $\begin{array}{c}16.0 \\
6.2 \\
24.7 \\
40.7 \\
11.1 \\
1.2\end{array}$ \\
\hline $\begin{array}{l}\text { Fathers age } \\
\text { Do not know the age } \\
\text { Deceased } \\
\text { 30-40 Years } \\
\text { 41-50 Years } \\
\text { 51-60 Years } \\
\text { 61-70 Years } \\
71 \text { and above }\end{array}$ & $\begin{array}{c}12 \\
8 \\
1 \\
11 \\
32 \\
16 \\
1\end{array}$ & $\begin{array}{c}14.8 \\
9.9 \\
1.2 \\
13.6 \\
39.5 \\
9.8 \\
1.2\end{array}$ \\
\hline $\begin{array}{l}\text { Mothers highest qualifi } \\
\text { Primary } \\
\text { Secondary } \\
\text { Tertiary } \\
\text { Islamic }\end{array}$ & $\begin{array}{c}\text { ication } \\
7 \\
20 \\
39 \\
15\end{array}$ & $\begin{array}{c}8.6 \\
24.7 \\
48.1 \\
18.5\end{array}$ \\
\hline $\begin{array}{l}\text { Fathers highest qualific } \\
\text { Primary } \\
\text { Secondary } \\
\text { Tertiary } \\
\text { Islamic }\end{array}$ & $\begin{array}{c}\text { cation } \\
2 \\
4 \\
70 \\
5\end{array}$ & $\begin{array}{c}2.5 \\
4.9 \\
86.4 \\
6.2\end{array}$ \\
\hline
\end{tabular}
dents was 20 years which fell within the first category of 15-20 years. More than half of the respondents were year one (1) students of the university with $55(67.9 \%)$,

Table 1. Socio-demographic characteristics of the studied respondents. 
while only $26(32.1 \%)$ were year two (2) students of the university. There were more single respondents (78) $96.7 \%$ than the married (3) $3.7 \%$. Majority of the respondents (78) $96.3 \%$ were Hausa by tribe while the

Table 2. Association between socio demographic variables and self-medication.

\begin{tabular}{|c|c|c|}
\hline Variables & Mean $( \pm S D)$ & $\mathbf{P}$ \\
\hline $\begin{array}{l}\text { Gender } \\
\text { Male } \\
\text { Female }\end{array}$ & $\begin{array}{l}1.3846(0.5436) \\
1.6429(0.5329)\end{array}$ & 0.019 \\
\hline $\begin{array}{l}\text { Age } \\
15-20 \\
21-25 \\
26-30 \\
31 \text {-above }\end{array}$ & $\begin{array}{c}1.5079(0.5350) \\
1.5625(0.6291) \\
2(-) \\
1(-)\end{array}$ & 0.881 \\
\hline $\begin{array}{l}\text { Level of study } \\
100 \text { Level } \\
200 \text { Level }\end{array}$ & $\begin{array}{l}1.4909(0.5399) \\
1.5769(0.5778)\end{array}$ & 0.586 \\
\hline $\begin{array}{l}\text { Marital status } \\
\text { Married } \\
\text { Single } \\
\text { Divorced }\end{array}$ & $\begin{array}{c}1.6667(0.5774) \\
1.5128(0.5523) \\
-\end{array}$ & 0.548 \\
\hline $\begin{array}{l}\text { Tribe } \\
\text { Hausa } \\
\text { Yoruba } \\
\text { Others }\end{array}$ & $\begin{array}{c}1.5256(0.5518) \\
1(0) \\
2(-)\end{array}$ & 0.596 \\
\hline $\begin{array}{l}\text { State of origin } \\
\text { Adamawa } \\
\text { Bauchi } \\
\text { Borno } \\
\text { Gombe } \\
\text { Kaduna } \\
\text { Kano } \\
\text { Kastina } \\
\text { Kwara } \\
\text { Nasarawa } \\
\text { Osun } \\
\text { Taraba } \\
\text { Yobe }\end{array}$ & $\begin{array}{c}1(-) \\
1.5965(0.5625) \\
1.5(0.7071) \\
1.5(0.7071) \\
1(-) \\
1(0) \\
1.67(0.5774) \\
1(-) \\
1.5(0.7071) \\
1(-) \\
1(0) \\
1.5(0.7071)\end{array}$ & 0.103 \\
\hline $\begin{array}{l}\text { Mothers age } \\
\text { Do not know the age } \\
\text { Deceased } \\
\text { 30-40 Years } \\
\text { 41-50 Years } \\
\text { 51-60 Years } \\
\text { 61-70 Years }\end{array}$ & $\begin{array}{c}1.69(0.4804) \\
1.6(0.5477) \\
1.7(0.6569) \\
1.3(0.4667) \\
1.5556(0.5271) \\
1.5185(0.5503)\end{array}$ & 0.082 \\
\hline $\begin{array}{l}\text { Fathers age } \\
\text { Do not know the age } \\
\text { Deceased } \\
\text { 30-40 Years } \\
\text { 41-50 Years } \\
\text { 51-60 Years } \\
61-70 \text { Years } \\
71 \text { and above }\end{array}$ & $\begin{array}{c}1.75(0.4523) \\
1.75(0.4629) \\
2(-) \\
1.2727(0.4671) \\
1.5625(0.6189) \\
1.25(0.4472) \\
2(-)\end{array}$ & 0.021 \\
\hline $\begin{array}{l}\text { Mothers highest qualifi } \\
\text { Primary } \\
\text { Secondary } \\
\text { Tertiary } \\
\text { Islamic }\end{array}$ & $\begin{array}{l}\text { cation } \\
1.2857(0.4879) \\
1.55(0.5104) \\
1.5385(0.5547) \\
1.533(0.6399)\end{array}$ & 0.852 \\
\hline $\begin{array}{l}\text { Fathers highest qualific } \\
\text { Primary } \\
\text { Secondary } \\
\text { Tertiary } \\
\text { Islamic }\end{array}$ & $\begin{array}{l}\text { ation } \\
\qquad 1.5(0.7071) \\
1.75(0.50) \\
1.5143(0.5580) \\
1.4(0.5477)\end{array}$ & 0.377 \\
\hline
\end{tabular}

remaining (2) $2.5 \%$ and (1) $1.2 \%$ were Yoruba and others respectively. Approximately, (57) $70.4 \%$ of the respondents were Bauchi State indigenes while the remaining where from Taraba (5) $6.2 \%$, Kastina (3) 3.7\%, Borno, Gombe, Kano, Nassarawa and Yobe States were (2) $2.5 \%$ respectively and Adamawa, Kwara, Kaduna and Osun states were (1) 1.2\% respectively. About 33 (40.7\%) of the respondents' mothers Age were 41-50 years while (13) $16 \%$ Do not know their mothers age, (5) $6.2 \%$ of the respondents' mothers were Deceased and (20) $24.7 \%$ were within the $30-40$ years and (9) $11.1 \%$ were $51-60$ years. Slightly below average of the respondents Fathers age fell within 51-60 years (32) $39.5 \%$ while (12) $14.8 \%$ do not know their fathers age, (8) $9.9 \%$ of the respondents' fathers were Deceased, (16) $9.8 \%$ were $61-70$ years and (1) $1.2 \%$ were $30-40$ years and 71 years and above respectively. Lastly, less than average of the respondent's mother's highest qualification was (39) $48.1 \%$ tertiary education, (20) $24.7 \%$ had secondary education, (15) $18.5 \%$ had Islamic education and (7) $8.6 \%$ had primary education while most of the respondent's father's highest qualification were; tertiary education (70) $86.4 \%$, Islamic education (5) $6.2 \%$, Secondary education (4) $4.9 \%$ and primary education (2) $2.5 \%$ (Table 1).

Mean $( \pm \mathrm{SD})$ self-medication was compared across different categorical variables (Table 2). There were two significant associations between the variables and selfmedication after the analysis and the variables were Gender and Fathers age.

From Table 3, the analysis shows that, (22) $27.2 \%$ of the respondents' reasons for self-medication was that the Doctors gives same drug, (20) $24.7 \%$ said the Disease was mild, (16) $19.7 \%$ knew the drug to take,

Table 3. Reasons for self-medication.

\begin{tabular}{lc}
\hline Reasons & Response (\%) \\
No Response & $12(14.8)$ \\
Saves Cost & $2(2.5)$ \\
\hline Saves Time & $9(11.1)$ \\
The disease is mild & $20(24.7)$ \\
\hline I know the Drug & $16(19.7)$ \\
Same prescription is expected & $22(27.2)$ \\
from the doctor & \\
\hline Difficult to have permit & -
\end{tabular}

(12) $14.8 \%$ had no response about their reasons while (9) $11.1 \%$ saves time and (2) $2.5 \%$ said it saved cost.

\section{Logistic regression predicting self-med- ication from gender}

Table 4 shows the logistic regression coefficient, Wald test and odds ratio for each of the variables. Employing a 0.05 criterion of statistical significance, Gender had significant effect. The odd ratio for Gender implies that when holding all other variables constant, a male medical student is two (2) times more likely to practice self-medication more than a female medical student.

\section{Discussion}

This study was conducted to serve as a basis for determining the prevalence selfmedication among medical students and to provide baseline information and of knowledge of the effects of antibiotics among medical students in college of medical sciences ATBU Bauchi, North East Nigeria. Self-medication (SM) is the intake of drugs without professional advice to treat self-diagnosed symptoms, illness or emotional ailments. ${ }^{7,17} \mathrm{SM}$ also refers to any habitual use of substance or any exogenous influence by an individual to treat common conditions and perceived minor health problems such as fever, headache, sore throat, intestinal colic, cramps, cold, pains and infections with medicines that are approved and available without prescription. ${ }^{6}$ The World Health Organization (WHO), on the other hand described Self-medication as a human behavior, in which a person takes drugs without professional advice to treat self-diagnosed symptoms or illness. ${ }^{18}$ Drugs and substance for self-medication are commonly dispensed over the counter, ${ }^{4}$ not consulted or prescribed by any physician are used for the treatment of common health issues at home. Several studies carried out in both developed and developing countries have shown that self-medication and inappropriate use of antibiotics is rampant among college students in which harm outweighs the benefit, and its inappropriate use may cause drug resistance, physical and mental health hazards and addicts which to some extent can influence professional decisions. ${ }^{11,19}$ Previous studies have also shown that self-medication practice and antibiotics use are driven by a lot of deter-

Table 4. Logistic regression predicting self-medication from gender.

\begin{tabular}{lcccc} 
Predictor & B & Wald chi-square & P & Odd ratio \\
Gender & -2 & 6.050 & 0.014 & 2.019 \\
\hline
\end{tabular}


mining factors such as socio economic and demographic factors, lifestyle, level of education, field, advertisements, ${ }^{5}$ advice from friends or relatives, readily available drugs. ${ }^{20}$

This study has established the prevalence of self-medication and knowledge of antibiotics use among medical students in North East Nigeria to be $41 \%$. This finding is very close to the prevalence rate reported in the study carried out among medical students in India, ${ }^{7}$ and lower than reported among medical practitioners in Ilorin, Nigeria by Fadare. ${ }^{11}$ Some higher rates were also reported by Montgomery in Greece where more than $50 \%$ of the medical students reported self-treatment and Egypt. $^{21}$

Our study revealed that the prevalence is higher among male medical students $(61 \%)$ than their female counterparts $(16 \%)$. The study therefore demonstrates that male students are more active SM practitioners than female medical students. This was contrary to that reported by Sharma with female prevalence at $77.4 \%$ and similar to that reported by Banerjee and Bhadury $(69 \%)$ and Gutema et al. (55\%). ${ }^{17,22,23}$

Positive correlation was observed between ethnicity and self -medication. The Hausa tribe had the highest number of those who practiced self-medication with (39) $91.5 \%$ compared to other tribes. The study further showed that majority of the respondents who practiced SM were from Bauchi state compared to medical students from other States. These findings could be attributed to the higher number of Hausas and Bauchi students among study participants compared with non-Hausas and non-Bauchi state students. The study further shows relationship between age and practice of SM because the median age among all respondents was 20 years which fell within the first category of 15-20 years. There was close association between self-medication practices and younger age group as reported in previous studies. ${ }^{24}$

Although slightly more than half of the respondents in this were year one (1) students of the college $55(67.9 \%)$. The SM prevalence was found to be higher among the first-year students compared with lower rate $26(32.1 \%)$ found year two (2) students as similarly found in a previous study with more than half of study participants that practiced self-medication were first year medical students. ${ }^{25}$

Interestingly, this study revealed the major reasons for self-medication among the medical students was that physician gives same drugs (22) $27.2 \%$, to another (20) $24.7 \%$ said the disease was mild, while (16) $19.7 \%$ felt they have good knowledge of the drugs to take. As high as (12) $14.8 \%$ had no reasons for SM practice while (11) $13.6 \%$ said it saves time and cost.

\section{Conclusions}

This study has for the first time established the prevalence of SM among Medical Students in North East Nigeria. The study shows males medical students being more active SM practitioners than female medical students. We found that SM and antibiotics use is more prevalent among first year medical students who just enrolled into university and drugs for SM can be purchased over the counter. Further studies are recommended to gain more understanding on the effects of self-medication practice among the medical students. Targeted campaign programs to decrease SM among medical students in North East Nigeria are required. Enforcement of laws and policies on unprescribed drugs and continuous monitoring of dispensaries/drugstores to issue drugs only on prescription are necessary to reduce self-medication among medical students.

\section{References}

1. Leape L. When good doctors go bad: a systems problem. Ann Surg 2006;244: 649-742.

2. Montgomery AJ, Bradley C, Rochfort A, Panagopoulou E. A review of selfmedication in physicians and medical students. Occupat Med 2011;61:490-7.

3. Kamran A, Sharifirad G, Shafaeei Y, Mohebi S. Associations between selfmedication, health literacy, and selfperceived health status: A communitybased study. Int J Prev Med 2015;20:666.

4. Mandal S. Can over-the-counter antibiotics coerce people for self-medication with antibiotics? Asian Pac J Trop Dis 2015;5:S184-6.

5. Sridhar SB, Shariff A, Anas D, et al. Assessment of Nature, Reasons, and Consequences of Self-medication Practice among General Population of Ras Al-Khaimah, UAE. Int J App Basic Med Res 2018;8,:3-8.

6. Alraddadi KK, Barakeh RM, Alrefaie SM, et al. Determinants of Self-medication among Undergraduate Students at King Saud University: Knowledge, Attitude and Practice. J Health Special 2017:95-101.

7. Kaylan V, Padma T, Pratap K, et al. Evaluation of self-medication practices among undergraduate dental students of tertiary care teaching dental hospital in
South India. J Educ Ethics Dent 2013; 3:21-5.

8. Lv B, Zhou Z, Xu G, et al. Knowledge, attitudes and practices concerning selfmedication with antibiotics among university students in western China. Trop Med Int Health 2014;19:769-79.

9. Cortez J, Rosário E, Pires JE, et al. International Journal of Infectious Diseases Antimicrobial storage and antibiotic knowledge in the community: a cross-sectional pilot study in northwestern Angola. Int J Infect Dis 2017; 60:83-7.

10. Ayanwale MB, Okafor IP, OO. Selfmedication among rural residents in Lagos, Nigeria. J Med Tropics 2017;19: 65-71.

11. Fadare J, Desalu O. Self-prescription practices by Nigerian medical doctors Self-prescription practices by Nigerian medical doctors. South Afr Fam Pract 2015;56:253-7.

12. Tsang S, Royse CF, Terkawi AS. Guidelines for developing, translating, and validating a questionnaire in perioperative and pain medicine. Saudi J Anaest 2017;11:S80-9.

13. Naghavi SHR, Shabestari O, Roudsari $\mathrm{AV}$, Harrison J. Design and validation of a questionnaire to measure the attitudes of hospital staff concerning pandemic influenza. J Infect Publ Health 2012;5:89-101

14. Deniz MS, Alsaffar AA. Assessing the Validity and Reliability of a Questionnaire on Dietary Fibre-related Knowledge in a Turkish Student Population. J Health Popul Nutr 2013; 31:497-503.

15. Montshiwa T, Moroke ND. Assessment of the Reliability and Validity of Student-Lecturer Evaluation Questionnaire: A Case of North West University. Med J Soc Sci 2014;5:20399340.

16. Jain S, Dubey S, Jain S. Designing and validation of questionnaire. Int Dental Med J Adv Res 2016;2:1-3.

17. Sharma A, Oommen S, Topno I, Saya RP. Perceptions and practices of selfmedication in healthcare and nonhealthcare university students in South India. J Basic Clin Physiol Pharmacol 2015;18.

18. Gupta S, Singh M. Self-medication among North Indian first - year undergraduate healthcare students: A questionnaire-based study. Trop J Med Res 2016;19:162-7.

19. Balhuena FR, Aranda AB, Figueras A. Self-Medication in Older Urban Mexicans, Observational, An Study, Cross-sectional. Drugs Aging 
2009;26:51-61.

20. Lopez JJ, Dennis R, Moscoso SM. [A study of self-medication in a neighborhood in Bogota]. Revista de Salud Publica. 2009.

21. Helal RM. Self-Medication in University Students from the City of Mansoura, Egypt. J Environm Publ Health 2017:1-7.

22. Banerjee I, Bhadury T. Medical stu- dents in a tertiary care medical college. West Bengal 2012;58:127-32.

23. Gutema GB, Gadisa DA, Kidanemariam ZA, et al. Self-medication practices among health sciences students: the case of Mekelle University. J Appl Pharmaceutic Sci 2011;1:183-9.

24. Kumar N, Kanchan T, Unnikrishnan B, et al. Perceptions and Practices of Self-
Medication among Medical Students in Coastal South India. PLoS Negl Trop Dis 2013;8:1-6.

25. Lukovic JA, Miletic V, Pekmezovic T. Self-Medication Practices and Risk Factors for Self-Medication among Medical Students in Belgrade, Serbia. PLoS One 2014;9:1-14. 